\title{
Landscape Function and Tourism Industry: A Case Study of Moc Chau Plateau, Vietnam
}

\author{
Hoa Thi Thu LE ${ }^{1}$, Binh Thanh TONG ${ }^{2}$, Ngoc Thi Minh VU ${ }^{3}$, Luu Si HO', Thang Viet PHAM ${ }^{5}$, Hang Thi Thu TRINH \\ Received: September 01, 2020 Revised: October 26, 2020 Accepted: November 16, 2020
}

\begin{abstract}
Tourism is not only a cultural service but also a resource consuming industry. Landscape function framework is a powerful tool to show the relationship between nature and people. This study collects 50 documents around the world to analyze the relationship between the 4 functional groups of the landscape (regulatory functions, production and supply functions, resident functions, information and entertainment functions) and the tourism industry. On that basis, we created an establishment for practical contact analysis of the goods and services of the landscape for tourism development in Moc Chau plateau, Vietnam. Research results show that tourism is an economic sector that benefits from the landscape and has a clear resource orientation. Moc Chau plateau has rich tourism resources and has the conditions to develop various types of tourism, especially cultural tourism based on community and resort tourism. The two cultural functions and the providing functions are the two most important functional groups for the tourism development of Moc Chau district, bringing the two most important tourism icons for Moc Chau, a green steppe, cool milk benevolent and also a district rich in national culture. From these conclusions, the authors give recommendations and notable points about landscapes in the tourism industry, especially in places with topography like Moc Chau.
\end{abstract}

Keywords: Landscape Function, Tourism, Moc Chau, Vietnam

JEL Classification Code: E44, F31, F37

\section{Introduction}

In practice, many goods and services of society have been directly and indirectly provided by landscape values (landscape services and ecosystems). However, most of the human perception holds that these values are naturally used, free of charge; Therefore, in the world as well as in Vietnam,

${ }^{1}$ First Author. Lecturer, Department of Geography, Tay Bac University, Vietnam. Email: lethuhoatb@gmail.com

2Lecturer, Department of History, Tay Bac University, Vietnam.

Email: binhtt@utb.edu.vn

${ }^{3}$ Lecturer, School of Economics and International Business, Foreign

Trade University, Vietnam. Email: ngocmvt@gmail.com

${ }^{4}$ Researcher, Department of Finance, Vietnam National University,

Vietnam. Email: luuhs@vnu.edu.vn

5Lecturer, Department of Business Administration, Vietnam National

University, Vietnam. Email: phamvietthang79@gmail.com

${ }^{6}$ Corresponding Author. Lecturer, Department of Economics

Development, Vietnam National University, Vietnam [Postal Address: 144 Xuan Thuy Street, Cau Giay District, Hanoi, 1000014000, Vietnam] Email: trinhhangtlu@gmail.com

(C) Copyright: The Author(s)

This is an Open Access article distributed under the terms of the Creative Commons Attribution Non-Commercial License (https://creativecommons.org/licenses/by-nc/4.0/) which permits unrestricted non-commercial use, distribution, and reproduction in any medium, provided the original work is properly cited. researches on landscape value have not been focused yet, leading to waste and exhausted resources and polluted environment. In economic activities, tourism is an important economic sector that benefits from landscape values because this is a clear resource-oriented industry (Skowronek, Tucki, Huijbens, \& Jóźwik, 2018). The simultaneous exploitation of landscape values for tourists is based on the diversity of landscape functions. This topic focuses on analyzing the relationship between landscape function and tourism. Moc Chau is a typical mountainous highland district of Northern Vietnam with charming scenery and abundant natural resources will be chosen as the site for us to apply the analysis of the arguments in the research.

\section{Theoretical Background}

The concept of landscape function has been mentioned by scientists in Moscow and Bantic in ecology studies since the 70s (Bakarasov, 2004). It is then discussed in more detail and specifically on the landscape planning system of Germany and in German-speaking countries (Ü. Mander \& Uuemaa, 2015). Accordingly, landscape energy is a combination of exchanging, changing material and energy processes in landscape (Ixatsenko, 1969) which 
is the flow of energy, mineral nutrition and organisms of landscape or fragmented interaction. discrete background (Forman, 1981). This view has focused on and promoted the natural characteristics and the internal processes of the landscape but is of a general nature, not yet clearly showing the landscape value.

According to this study, the authors agree with (De Groot, 1992; Groot \& Hein, 2007; Bastian, 2000; Alcamo, 2003; Kumar, 2010) on landscape functions: The landscape is capable of providing goods and services of natural processes and elements to meet the direct or indirect human needs. In Vietnam, similar ideas were found in the research of (Pham, Nguyen, \& Nguyen, 1997; Nguyen, 2003; Nguyen, 2019). This view is more evident from the deep structure of the landscape and the intrinsic processes within the landscape. Landscape structure regulates the ability of humans to provide landscape goods and services. A landscape unit often offers many different services and goods at the same time called a multifunctional landscape. In this study, the author selects the landscape function framework of the United Nations economic organization on ecosystem and biodiversity (Kumar, 2010) This frame is consistent with the characteristics of the mountain landscape.

\section{Data and Methods}

\subsection{Research Data}

To study the landscape function framework and the relationship between landscape function and the tourism industry, the study used 50 domestic and foreign research works including landscape materials, landscape ecology, and geography travel agents. Online database searches from Science Direct, World Tourism Organization, Springer link, many text documents on tourism geography, tourism resources of Vietnam and Moc Chau district were also used. In addition to that for calculating the tourism climate index, we use the monthly average data on climate factors at Moc Chau station, Son La province for 10 years from 2008 to 2018.

\subsection{Research Methods}

\section{Summarizing and analyzing documents method}

Summary of landscape functional documents, assessment of ecosystem services, the role of services with tourism, documents about natural resources, humanities and Moc Chau tourism. Documents providing knowledge of landscape function, the relationship between landscape function and tourism in the World, Vietnam and Moc Chau scales.

\section{Surveying, fielding method}

In geographic research, especially natural geography and tourism geography, the survey method helps to approach the problem proactively and visually to make reliable judgments. The activities of this method include observation, recording, description, photography, and interviews to clarify the characteristics of spatial distribution of tourism resources over time and space.

\section{Mathematical methods}

Climate is both a resource and an important factor for tourism development. The study used the calculating method of the comfort tourism climate index Mieczkowski (1985) to find out the best weather time for Moc Chau district.

Table 1: Functional groups of landscape and ecosystem

\begin{tabular}{|c|c|c|}
\hline Regulatory function & Supply function & Cultural function \\
\hline $\begin{array}{l}\text { Benefits derived from the } \\
\text { landscape processes of the } \\
\text { ecosystem } \\
\text { Climate control } \\
\text { Air filter } \\
\text { Water regulation } \\
\text { Water filter } \\
\text { Diseases reduction } \\
\text { Pollination }\end{array}$ & $\begin{array}{l}\text { Products obtained from } \\
\text { Landscape and ecosystem } \\
\text { Food and fiber } \\
\text { Water } \\
\text { Fuel } \\
\text { Pharmaceutical products } \\
\text { Jewelry and other products } \\
\text { Activity space }\end{array}$ & $\begin{array}{l}\text { Intangible benefits from landscapes and } \\
\text { ecosystems } \\
\text { Diversity of culture } \\
\text { Legacy } \\
\text { Spiritual and religious values } \\
\text { Artistic inspiration } \\
\text { System of knowledge and education } \\
\text { The aesthetic beauty of the landscape } \\
\text { Travel and entertainment }\end{array}$ \\
\hline \multicolumn{3}{|c|}{$\begin{array}{l}\text { Habitat function } \\
\text { ersity and evolution of ecosystems } \\
\text { of rare and endemic species } \\
\text { environment of migratory species }\end{array}$} \\
\hline
\end{tabular}




\section{Results and Discussion}

\subsection{Relationship between Landscape Function and Tourism}

\section{Cultural function for tourism development}

For tourism, cultural functions are extremely important, especially information and entertainment function. Information and entertainment functions providing invisible and intangible goods and services to humans. Products include: spirituality and belief, cultural, educational and scientific heritage, aesthetics, artistic inspiration, tourism and entertainment.

Cultural and ethnic objects associated with the humanities of the landscape are important human resources for tourism. Culture is the material values and spiritual values that people have accumulated during their lives through productive labor. Ethnic culture has become an important material in the creation of tourism products. In the context of globalization today, cross-cultural intercourse makes many of the original values being lost, so the search for cultural differences by tourism is on the rise. Ethnic attributes are considered as an asset and tourism can promote the restoration of national cultural values. It also shows that local community involvement offers greater opportunities and opportunities to maximize the potential of untapped areas. (Chamidah \& Sulastri, 2020)

Cultural heritage is considered a "gift from the past to the future". This is a special form of tourism resources, containing irreplaceable cultural and historical values. Through cultural heritage, visitors learn about history and culture. In addition to that the natural heritage containing biodiversity, ecosystem and geological values, it becomes the basis for developing cultural tourism, ecotourism, sightseeing, discovery and tourism in association with education. educational history. The combination of tourism and heritage creates conditions to enhance knowledge, inspiration and destination tourism for visitors. Heritage sites and monuments are not just sources of income for tourism, but also create jobs for local people.

In addition to cultural values, the history of each landscape unit also contains knowledge about flora and fauna as well as the environment. The rich value of landscape units will meet the diverse needs of visitors from sightseeing, experience to awareness, learning. Therefore, the trend of research on ecotourism, community tourism, cave tourism, and heritage tourism is growing, which shows the multi-dimensional values of the landscape for the tourism industry.

Besides, there are special landscape units, which contain roots of philosophy, beliefs, human and supernatural connections. The value of this landscape exists with the presence of temples, pagodas, holy places, spiritual lands, and festivals of the nation. This is the basis for creating a specific type of tourism - Pilgrimage tourism. "to satisfy pilgrimage needs, strengthening spiritual values, relieving stress, transforming all mental afflictions through a spiritual trip to the sacred places that pilgrims desire" (Giang, 2011).

In addition, cultural functions are also concretized as aesthetic and artistic functions. Artistic inspiration is perceived by people from the landscape and expresses the artistic works such as paintings, embroidery, ceramics, in music; it is a tourism product, creating attraction for the place and the local cultural identity. The paintings of nature by Van Gogh, Henri Rousseau, and Paul Cezanne are excellent examples of artistic inspiration becoming a tourism product in the Netherlands and France. Today, around the world, Korea is a country that strongly attracts tourism from the cultural function of the landscape. Korean cultural trend is called "Hallyu" and covers all areas related to Korea such as K-pop, K-drama, K-movies, K-hi-tech-lifestyle, K-culture, together with $\mathrm{K}$-cuisine, literature and linguistic traditions. These factors not only promote the tourism industry, but also creates a driving force for the consumption of products such as cosmetics, fashion and Korean cuisine to the foreign tourists (X. T. Nguyen, 2020).

The aesthetic beauty of the landscape has direct and important implications for tourism. Aesthetic beauty creates attraction for the tourism industry. In many countries around the world, the aesthetic beauty of the landscape becomes the image representing national tourism, also known as the "tourism symbol" of the country. In the world today there are 30 outstanding tourist symbols such as Angkor temple (Cambodia), Eiffel Tower (France), Taj Mahal (India), Great Wall of China (China), Mount Fuji (Japan). For Vietnam, Ha Long Bay is a representative symbol for tourism.

Through the above analysis, it is possible to confirm the cultural function values of the landscape for tourism development. The landscape is a place to rest, relax and inspire, improve your mental and physical health. The recreational and aesthetic values of landscapes in a number of countries have been specifically quantified to provide the basis for various economic activities. In 2018, Hermes and his associates took three targets: the diversity, nature, and uniqueness of landscape units to assess and create aesthetic maps, creating the basis for tourism development for whole Germany (Hermes, Albert, \& von Haaren, 2018)

\section{Production and supply of goods and services for tourism function}

As it contains many values, the function of producing and providing goods and services of the landscape for tourism is diverse: From providing food, water, medicine, minerals to space. Appreciating the value and function of the landscape will contribute to the effective exploitation of tourism potentials as well as create branded tourism products of each locality. 
The landscape contains a source of food; local specialties are the substrate for tourism development. According to (Telfer $\&$ Wall, 2000), an average visitor spends $1 / 3$ of the money on food trips. Food and local specialties are an important factor influencing the identification and decision making of many tourist destinations as well as maintaining the destination and maintaining that tourist identity (Lin, Pearson, \& Cai, 2011). Each local specialty is a geographical guide for visitors to explore, learn about geography, people and local culture. This is also a solid basis for the development of agriculture tourism, and culinary tourism. In a study of 476 tourists in Pattaya (Thailand), local food here is considered by tourists a cultural experience with a unique style of service, delicious, nutritious and exotic food. This is also an important factor determining the return of visitors (Lertputtarak, 2012).

The landscape also contains water supply for tourism activities. The tourism industry needs large amounts of fresh water for cooking, laundry, toilets, showers, swimming pools, cooling or watering gardens, as well as using water for various activities, etc (Gössling, Hall, \& Scott, 2015). Research results of the European Commission (2017) on the relationship between ecosystem services and tourism in 11 pilot cities (Florence, Nice, Lisbon, Syracuse, Copenhagen, Kavala, Santander, Nicosia, Ponta Delgada, Dubrovnik - Neretva District, Tenerife) show that fresh water is the most important factor (11/11 cities studied). To continue, heritage value ranked No. 2, local food ranked third, followed by other services. In particular, natural mineral water is a resource to develop tourism in many countries around the world such as Korea, Vietnam, and Japan with health care services, and construction of hot spa baths to serve tourist service. Research on "Trends in developing health tourism in the world today" has statistics: Japan has 26,000 hot mineral springs nationwide, with 3,000 resorts with hot mineral springs (also called orsen), which serves an average of 145 million visitors a year (Ha, 1997).

Besides, the landscape contains a source of valuable medicinal herbs - a basis for health care tourism development. At Stara Planina in Siberia; Isfahan of Iran and some places thanks to the large source of medicinal materials, attract a lot of other types of tourism, the lives of people have improved significantly (Ratknić \& Milovanovic, 2016) (Torabi Farsani, Zeinali, \& Moaiednia, 2018). In Vietnam, this service has been implemented quite effectively in the tourism industry and is evidenced by the brand of the tobacco bath by Red Dao minority in Sapa.

Not only that, the landscape contains sources of metals, gems, and products exploited to produce souvenirs - one of the memorabilia for tourists. Many countries consider handicrafts and fine arts to be the core of the tourism industry, as the image and attraction for the destination.

In particular, the landscape also provides space for tourism activities: A place to build infrastructure for the tourism industry such as hotels, restaurants, swimming pools, golf courses, amusement parks, and airports to develop different types of tourism. The Central Highlands gong cultural space spread across 5 provinces of Kon Tum, Gia Lai, Dak Lak, Dak Nong and Lam Dong in Vietnam is a testament to the value of space for tourism development and cultural preservation. Normally in mountainous areas, the index is large and diversified in landscape, so it can develop more types of tourism than plain areas. This fact shows that the assertion of A.N Dunet (2013) is completely based on

"Mountainous landscape has large fragmentation in different ranges. The reason is due to the difference in natural conditions, cultural and social groups, so the mountainous area is very convenient for tourism development."(Dunets, A. N, 2013)

\section{Regulatory function for tourism development}

Regulation and conservation functions are very important to the tourism industry, ensuring normal activities. Climate and harmonious environmental factors will create destination attraction, creating the basis for the type of resort tourism, and for medical treatment. Study the tourism climate index (TCI) of Mieczkowski (1985), the beach tourism climate index $(\mathrm{BCI})$ of is one of the concrete evidence of the impact of environmental factors on human health as well as tourism (Morgan et al., 2000). Research shows that environmental disturbances such as storms, floods, and climate change have a direct impact on tourism in many parts of the world such as Himalaya in Nepal (Nyaupane \& Chhetri, 2009)

In Vietnam, right from the French period, the role of climate and resort was paid special attention by the French. In the context we can say that the French soldiers were familiar with the cool and moderate temperate climate, it is very difficult to endure the harshness of the tropical climate, hot and humid. The need to find a resort for French soldiers was urgent. The Governor-General of Indochina issued a request to:

"look for a fresh highland region, where Europeans can enjoy the same resurgent, temperate climate similar to southern Europe and thus, can restoring health and intelligence" (Paul Doumer, 1897).

Scientist and explorer Alexandre Yersin headed the expeditions from 1892 to 1894 in order to "search for Switzerland in Indochina" to discover Da Lat. He likened "the Lang-Bian climate is similar to the Mediterranean climate in the spring"; the French chose to build the resort here in 1897. Later the resorts were built in $\mathrm{Ba} \mathrm{Na}, \mathrm{Sa} \mathrm{Pa}$, Tam Dao, Mau Son (Adapted from Jennings, 2015). These results illustrate the value of the regulatory function of the landscape in tourism throughout the periods.

Currently, climate change with the effects of extreme weather factors is directly affecting the tourism industry of our country such as destroying tourism infrastructure, tourism resources, interrupting travel activities (Nha, 2018). 


\section{Resident function group (habitat services)}

The landscape provides habitat for reproduction, thereby maintaining biodiversity, creating a premise for eco-tourism. Nature-based tourism includes activities: wildlife watching, scuba diving or tourism in protected areas. Wildlife and biodiversity make a significant contribution to attraction, quality, competitiveness of destinations. For example, the quality of coastal water and natural vegetation are both ecosystem services that contribute to destination attraction. According to the World Tourism Organization, all types of tourism depend on biodiversity, even tourism in the city center needs food, clean water and other services which is dependent on biodiversity (UNWTO, 2010). Tourism development in many other locations of the world is based on biodiversity and ecosystem services, for example, tropical rainforest landscape is famous for its remarkably high species diversity, which accounts for about $6 \%$ of land area, containing more than half of the world's species, has contributed greatly to the tourism industry of many countries such as Costa Rica, Ecuado, India, and Thailand (Gössling, 1999). In southern African countries, the savan landscape with a variety of wildlife has brought tourism greater than the agroforestry and fisheries combined (Balmford et al., 2009). In addition, the ocean landscape zone is the habitat and development of coral reefs, creating important attraction for coastal tourism of more than 100 different countries and territories. About $30 \%$ of the world's coral reefs are valuable in the tourism sector, with an estimated total value of nearly US $\$ 36$ billion, which is equivalent to more than $9 \%$ of the total coastal tourism value of the above reef countries of the the world (Spalding et al., 2017). The landscape of the mountains and plateaus has a high diversity of ecosystems - natural, semi-natural and cultivated (e.g. forests, cliffs, pastures, and traditional farming) to develop tourism in sync with ecology and nature.

It can be noticed that biodiversity has significant potential in tourism but the reality is that it is seriously threatened worldwide. The development of the tourism industry has partly led to the loss of ecosystems, especially coastal, desert and mountain ecosystems. The current requirement is to create a combination of tourism and biodiversity work to achieve common goals. The tourism industry needs to protect biodiversity as a valuable asset, making a lasting contribution to the success of the tourism industry.

\subsection{Landscape Function with Tourism Development in Moc Chau Plateau, Vietnam}

\subsubsection{Overview of Moc Chau District}

Moc Chau is a mountainous district of the karst plateau in Northwest Vietnam. The natural area of $1,081.66 \mathrm{~km}^{2}$ ranks $8^{\text {th }}$ among 12 city districts of Son La Province (People's Committee of Moc Chau district, 2015). According to author
Pham Hoang Hai et al, Moc Chau belongs to the highland landscape class in the horizontal classification system of Vietnamese landscape, with characteristics of climate, ecology and human life (Pham, 1990). Moc Chau tourism is characterized by mountain tourism

"Tourism activity takes place in a defined and limited geographical space such as hills or mountains with distinctive characteristics and attributes that are inherent to a specific landscape, topography, climate, biodiversity (flora and fauna) and local community"(UNWTO, 2018)

Strengths for Moc Chau tourism development were soon detected by the French when searching for resorts for French soldiers. It has been recorded in the documents for sanatoriums establishment in Lao Cai, Vinh Yen and Son La from 1904 to 1919 :

"Moc Chau Plateau: cooler and less moist than Tam Dao, wider than Sapa. From May to September the temperature does not exceed 23 to 24 degrees Celsius, more pleasant than $\mathrm{Sa}$ Pa, Tam Dao, Liang Bian and Tran Ninh. Located near Hanoi (157 km from Hanoi)"(File Number 74505. RST. A.s Creation of Sanatoriums in the Provinces of Laokay, Son La, Vinh Yen 1904 - 1919, 1919).

However, Moc Chau is not invested in tourism like other areas due to political calculations and difficulties in transportation, human resources, the opportunity to develop tourism in Moc Chau a century ago was missed. Studying goods and services for tourism in Moc Chau is the link for the landscape functions with the quality of livelihoods and putting people in the position of conservationists when exploiting tourism.

\subsubsection{Regulatory Function Creates Ideal Climate Conditions for The Development of Resort Tourism in Moc Chau}

Moc Chau is distributed on the terrain with an average elevation of more than $1,050 \mathrm{~m}$ above the sea level. The annual average temperature of Moc Chau is $18.7^{\circ} \mathrm{C}$, it has cool climate due to lying between the Da River (northeast) and Ma River (southwest). These two river systems act as two natural air conditioning systems. At the same time, Moc Chau has a high climate division along the belt, so it has both the characteristics of the subtropical and temperate highland climate, which is very convenient for developing tourism for the whole year. In order to measure the appropriate time for local tourism development, the author and his colleagues applied the method of calculating the tourism climate index (TCI) for Moc Chau district. The results show that: there are two months in the year where the tourism climate index is excellent (March and 
November); four months with a very good tourist climate index (months 2,4,10,12); three months have good TCI $(1,5,9$ months); Three-month tourism climate index reached the lowest level (May 5,6,7) but still acceptable in the general classification. The extreme weather events affecting Moc Chau tourism include: Storm in June, cold weather, fog in January ... Storms caused landslides on National Road 6, making it difficult to move and conduct visitors' outdoor travel experience. In January, due to the effect of the polar air mass, the cold, fog and reduced visibility made it difficult for traffic, the safety of the trip as well as the health of visitors. However, Moc Chau is undeniably has the most favorable climate condition to develop resort tourism in the Northwest region of Vietnam.

\subsubsection{Production and Supply Functions - Resources for Developing Agricultural Ecotourism in Moc Chau}

Moc Chau has a relatively flat terrain, temperate climate and thick soil layer, giving this region the ideal conditions for developing a diverse structure of clean and unique agricultural products. Specifically, tea and immense wavy green tea hills, with a total area of 1,822 hectares of high landscape and ecological value. The famous tea hills include Taiwan Heart Tea Hill (Nong Truong town), Moc Suong tea plantation hill (Tan Lap village 1,2), Tan Lap tea hill 3. Not only that, Moc Chau is deemed as "the paradise of dairy cows in Vietnam" with a herd of about 20,000 individuals, giving delicious products from milk (fresh milk, milk cake, and fresh yogurt) famous throughout the country (People's Committee of Moc Chau district, 2016).

Especially, Moc Chau is also known for its temperate fruit garden of 2,637 hectares, with high quality fruits such as prunes, peaches, strawberries, avocados, brittle persimmons, etc. The total area of Moc Chau's safe vegetables and high quality flower gardens is 105 hectares. In particular, the orchid, rose, lily and specialized gardens possess a great attraction; sturgeon and salmon farms are famous for their high quality, etc. In addition, the Moc Chau flora contains 160 species used for food (vegetables, spices, fruits, and tubers) (Dinh, 2017). The agricultural ecosystem has provided attractive services for Moc Chau tourism, the agricultural landscape has become a tourist attraction such as $\mathrm{Na}$ Ka plum valley, heart tea hill and $\mathrm{Ba}$ Phach flower fields, etc. On the other hand, agricultural products have become gifts and souvenirs for tourists to enjoy and give to their loved ones such as plums, peaches, milk, butter, brittle persimmons, etc. Promoting that strength, Moc Chau has processed diverse and delicious dishes, leaving an impression on visitors. One of the famous delicacies: village pig, hill chicken, taro, „cai meo“ cabbage, calf cooked with soya cheese, salmon, bambootube rice, grilled meat, etc. Therefore, Moc Chau has enough favourable conditions for agricultural ecotourism to become the most important type of tourism, in which agricultural products and dishes play as an attractive force for their originality and deliciousness

Forest ecosystems and organisms in Moc Chau have great medicinal potentials but have not been exploited for medical tourism. Landscapes and ecosystems in Moc Chau have great medicinal potentials. Moc Chau forest has 337 different medicinal species, accounting for $31.55 \%$ of the whole flora, the largest among the districts in Son La province. Some valuable medicinal plants can be named such as Drynaria fortunei, Elephantopus mollis, Codonopsis pilosula, Multiflorous knootweed, Cibotium barometz, Millettia reticulata, etc. Notably, there are many valuable medicinal plants that belong to conservation group in Vietnam Red Book (2007) and Decree 32/NDCP (2006) such as Vernonia amygdalina (Mahonia heali Carr), Anoectochilus, Polygonum multiflorum Thunb, and Codonopsis pilosula, etc (Dinh, 2017). Currently, people only exploit about $23 / 337$ species to treat common diseases such as flu, aches and pains, hemostasis, etc. while this is a valuable resource for health care of people. If this aspect is paid attention to and is properly used then medicinal plants will provide good support to develop medical tourism along with other attractions, creating more attraction for Moc Chau tourism.

Moc Chau plateau has Da river flowing through with Van Yen river bank. This is an important waterway intersection, opening the tour along the Da River with many beautiful scenes containing many unique cultural and historical imprints of the Northwest peoples. The Da River connects with the lake of two large hydroelectric plants in Southeast Asia, Son La and Hoa Binh plants, which are attractive destinations for many tourists. Stream system such as Quanh, Tan, Muong, etc. has both connected with one another and created fascinating landscapes. Streams flows on a narrow and sloping profile creating a beautiful waterfall like Dai Yem waterfall in Muong Sang commune. Because the water is relatively clean together with its favourable $\mathrm{PH}$ and temperature, some households in Chieng Di hamlet have taken it as an advantage for salmon farming. Salmon in Chieng Di is famous for its delicious and quality taste, which has attracted a large number of visitors to the farming and enjoying the farming models.

The two prominent handicraft industries of Moc Chau are weaving and brocade weaving, in which the materials is derived from the ecosystem. The most outstanding is the weaving of the Thai and Mong people with textile products such as towels, shirts, skirts, bags, etc. whose main materials are jute, linen, and beeswax. With vibrant colors and meticulous embroidery, brocade products are unique ones that charm visitors to the every item. 


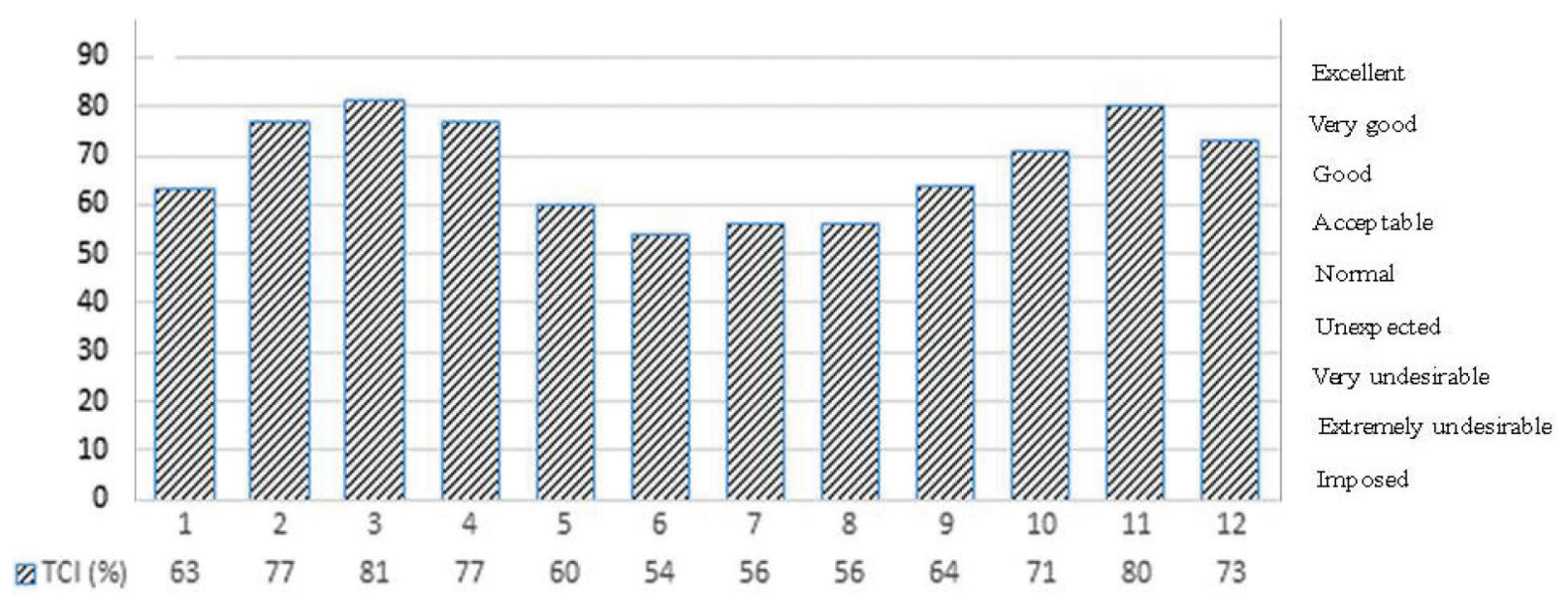

Figure 1: Changes in $\mathrm{TCl}$ of $\mathrm{Moc}$ Chau district in months of the year

Source: (H. T. T. Le, Nguyen, Trinh, \& Viet, 2020)

\subsubsection{Cultural Function - The Basis for Moc Chau To Develop Many Different Types of Tourism}

The unique multi-colored local culture is the basis for Moc Chau to develop community-based ecotourism and tourism associated with the national culture. According to the Statistical Yearbook of Son La Province in 2019, the total population of Moc Chau is 113,300 people with 10 ethnic groups including Kinh, Thai, Mong, Muong, Dao, Xinh Mun, Tay, and Kho Mu (Son La Statistical Office, 2019). Moc Chau is a land with a long history; since Hung Vuong period, Moc Chau was part of the territory of the State of Van Lang and $\mathrm{Au}$ Lac. This land is the gathering place of many ethnic groups, associated with the exploitation of ancient Vietnamese people, the process of migration and living of the Thai people from the beginning of the fourteenth century, and the program of reclamation, economic and cultural development of the Kinh people from the early 1960s of the twentieth century. The ethnic minorities residing in Moc Chau mainly live in villages in intertwined and merging way on the land of the plateau. Therefore, the phenomenon of bilingual and multilingual, bilcultural and multicultural practice is a specific feature of the cultural identity of the Northwest people in general and Moc Chau in particular. The unique and cultural diversity of the Moc Chau ethnic group is an important resource for Moc Chau to develop community and cultural tourism. The families there welcome guests to experience culture with a homestay model.

Currently, Moc Chau has about 80 homestay households, concentrated in Ban Ang area and Dai Yem waterfall, which is mainly of the Thai people, a small number in the
Pa Khen area belongs to the Mong people. Doi village (Tan Lap commune) and Vat village (Dong Sang commune) are currently being planned as a community tourism village.

It can be seen that many cultural values and resources for tourism development are preserved among the people but the life of the community is still difficult and vulnerable. According to 2019 statistics, the number of poor households who are ethnic minorities is 1,159 households (Son La Statistical Office, 2019). Most of them have not exploited the resources for tourism or if any of them have been exploited then it has been alone and spontaneous. The total number of homestays in Moc Chau is about 80 households but most of the people lack necessary skills to to indulge in tourist activities properly, potentially losing their cultural identities. The fact that shortterm tourism, tourism activities and profits dominated by tour operators is ongoing. Community approachment and exploitation of tourism will help people reduce dependence on forest land as well as maintain their cultural identity. Thus, improving the lives of the Moc Chau ethnic community is also creating conditions for disadvantaged people, reducing the gap between the communities in the district.

Moc Chau landscape covers its heritage and relics associated with the cultural tradition and history of the resistance against the French colonialism and American imperialism, including: Monument of hatred in Moc Chau Town, Monument of the $52^{\text {nd }}$ Tay Tien Regiment, a relic where Uncle Ho visited and talked to officials and workers of Moc Chau farm, historical relics of $83^{\text {rd }}$ Army of Vietnam Volunteers, Vat Hong Pagoda (Moc Chau district), etc. as foundations to develop cultural tours associated with education and learning the patriotic traditional history. 
Table 2: Summary of the multiculturalism of the Moc Chau ethnic groups

\begin{tabular}{|l|l|}
\hline Type name & \multicolumn{1}{|c|}{ Demonstration } \\
\hline Type of culture & $\begin{array}{l}\text { Cultural aspects cover valley and rice of the Thai people; hill and upland rice of Sinh Mun, Mong, } \\
\text { Dao, and Kho mu ethnic groups, etc. }\end{array}$ \\
\hline Architecture & Stilt houses (Thai, Muong, Kho Mu, and Xinh Mun), Earth homes (Kinh, Mong, and Dao) \\
\hline Costumes & $\begin{array}{l}\text { Casual clothes, festive, wedding, and funeral costumes etc. of the ethnic groups: Thai, Muong, } \\
\text { Xinh Mun, Kho Mu Muong, and Dao. }\end{array}$ \\
\hline Cuisine & $\begin{array}{l}\text { Thai cuisine is famous for its fish salad, meat salad, dried buffalo meat, Chinese sausage, kebab } \\
\text { meat, steamed rice, sticky rice with five colors, sour bamboo shoots, sweet and sour grated } \\
\text { salads, sour dishes, "bon" soup, corn wine, straw liquor, leaf wine; Mong cuisine is typical with } \\
\text { specialties such as rice pie, steamed cornmeal, hanging - kitchen meat, sprouting rice wine; Dao } \\
\text { cuisine includes buckwheat wine, taro soup and so on. }\end{array}$ \\
\hline Folk dances & $\begin{array}{l}\text { Syrinx dancing and umbrella dancing of the Mong people; Dao dancing style and bell dancing of } \\
\text { the Dao; Xoe dance and scarf dance of the Thai people; Grain dance, Tang bu dance of the Xinh } \\
\text { Mun people. }\end{array}$ \\
\hline Folk songs & $\begin{array}{l}\text { Khap dance of the Thai people, Tom sing of the Kho Mu, Dang sing Tof the Muong people, and } \\
\text { love singing of the Mong people }\end{array}$ \\
\hline $\begin{array}{l}\text { Traditional } \\
\text { craftsmanship }\end{array}$ & $\begin{array}{l}\text { Knitting, weaving, and dying of the Thai and Mong people, blacksmithing and papermaking of the } \\
\text { Mong people, wax prints of the Dao ones, etc. }\end{array}$ \\
\hline $\begin{array}{l}\text { Traditional festival } \\
\text { Folk games }\end{array}$ & $\begin{array}{l}\text { Het Cha Festival, Traditional New Year of the Mong people, Independence Day of the Mong } \\
\text { people 2/9, praying for rain, new rice festival, Moc Chau love market, tea festival, and fruit picking } \\
\text { festival. Archery, crossbow shooting, and throwing cotton ball game }\end{array}$ \\
\hline $\begin{array}{l}\text { Indigenous } \\
\text { knowledge }\end{array}$ & $\begin{array}{l}\text { Knowledge of cultivation on sloping land of the Mong people, water reels, ditches, dams, and } \\
\text { guiding water through obstacles of the Thai people }\end{array}$ \\
\hline
\end{tabular}

Moc Chau is a part of the Triassic limestone plateau running from Phong Tho to Thanh Hoa, a geosyncline of the Da River with a turbulent history dating back 500 million years (B. Le, 1977). Unique geological heritage is Bat Cave and Five Caves of On Village, in which, Bat Cave has an area of $6,915 \mathrm{~m}^{2}$, in addition to its beautiful and unique stalactite system, the cave also contains traces of the ancient Viet people from 3000 to 3500 years ago: stone slabs, ax sharpening blades, stone balls, and ceramic pieces. This is the basis for Moc Chau to develop geological tourism associated with education and scientific research.

Currently, Bat Cave and Moc Ly Post are two relics classified as national monuments and six monuments classified as provincial relics. Heritage sites and monuments are important destinations in the operation of tours and tourism routes.

The value of landscape spirituality in Moc Chau is symbolized in 2 factors: Festivals and spiritual places (i.e pagodas): such as Rain praying festival in $\mathrm{Na}$ Bo village, Muong Sang commune, where people will pray to heaven and earth for rain and water for a good harvest. Het Cha festival of the White Festival of the White Thai in Dong Sang is celebrated to express thanks and gratefulness to heaven and earth as well as celestials for a peaceful year with good crops, and thank doctors for their cures to the villagers. In 2015, Het Cha festival is recognized as a national intangible heritage. Accompanied by festivals are cultural activities of the community, including dancing, throwing, and singing folk songs to praise the love of couples and encourage people to love work. In addition, Moc Chau also has vestiges of Vat Hong pagoda. According to "The Đại Nam nhất thống chí" (National History of the Nguyen Dynasty), Chien Vien Pagoda (Vat Hong) is the largest and oldest Buddhist architecture in the Northwest mountainous region, this is a holy place for the people of Moc Chau and is visited by tourists every Tet holiday (National history of the Nguyen Dynasty, 1992). Festivals and spiritual places are the basis for Moc Chau to develop spiritual tourism associated with traditional historical education for the younger generation.

Up to now, Moc Chau is considered to be the most beautiful plateau in the Northwest region of Vietnam. The beauty of Moc Chau landscape is created by majestic mountains combined with flat and open plains. The highlight along Moc Chau roads is the green tea hills, plum gardens, rape follower valleys, and the vivid colors of ethnic Mong and Thai costumes, etc. The continuity of the flower and orchard seasons in the year makes the establishment of tour plans convenient with diverse tourism products. With local 
efforts, Moc Chau tourism image and brand is becoming familiar and attracting other tourists with the symbol "Green meadow, fresh milk", tea hills and tea products with many preferable brands and fresh climate. The above symbols have formed the unique features and are an effective competitive resource of the Moc Chau tourism brand. For Moc Chau tourism, the landscape has 4 main functions: culture, production, regulation and residence. This has created a variety of types of tourism in Moc Chau: resort tourism, ecotourism, tourism associated with education, heritage tourism, and agricultural tourism, etc. It should be noticed that Moc Chau ecosystem is a sensitive mountain ecosystem, vulnerable to climate change and environmental factors. In order to maintain the diverse landscape functions for tourism development in Moc Chau, the authorities need to be professional and serious in planning and managing tourism services as well as in supporting business people involved in tourism activities in a professional way through equipping themselves with knowledge of the landscape conservation and tourism services. Only when the landscape is respected and protected only then tourism business will be able to contribute in promoting landscape function and improving sustainable livelihoods for people.

\section{Conclusion}

Analyzing the relationship between landscape function and tourism is to demonstrate the value of natural resources and tourism. The flow of ecosystem goods to the economy in general and the tourism industry in particular needs to be clearly delineated towards sustainable resource usage and exploitation. The study has based on the landscape function framework to clarify: Moc Chau highland district enjoys many benefits from nature to develop tourism. Services and functions of mountain ecosystems in the mountainous district of Moc Chau in Northwest Vietnam have contributed greatly to the regulation, supply, conservation and habitat of the tourism industry. These functions need to be exploited with conservation to ensure diversity and should be maintained for a long time. Tourism is a resource-consuming industry, so raising awareness among the local community and planning tourism in a scientific way is an important task today.

\section{References}

Alcamo, J. (2003). Ecosystems and human well-being: A framework for assessment. Washington, DC: Island Press.

Bakarasov. (2004). Ecology of landscapes. Lecture course. Head: Belarusian State University. Subject: Geoecology. University: BarSU. Retrieved September 16, 2020, from StudFiles website: /preview/6878005/

Balmford A., Beresford J., Green J., Naidoo R., Walpole M., \& Manica A. (2009). A Global Perspective on Trends in Nature-
Based Tourism. PLOS Biology, 7(6), e1000144. https://doi. org/10.1371/journal.pbio.1000144

Bastian, O. (2000). Landscape classification in Saxony (Germany): A tool for holistic regional planning. Landscape and Urban Planning, 50(1), 145-155. https://doi.org/10.1016/S01692046(00)00086-4

Chamidah, N., \& Sulastri, E. (2020). Marketing Communication and Synergy of Pentahelix Strategy on Satisfaction and Sustainable Tourism. Journal of Asian Finance, Economics and Business, 7(3), 177-190. https://doi.org/10.13106/jafeb.2020. vol7.no3.177

De Groot, R., \& Hein, L. (2007). Concept and valuation of landscape functions at different scales. In: Ülo Mander, H. Wiggering, \& K. Helming (Eds.), Multifunctional Land Use: Meeting Future Demands for Landscape Goods and Services (pp. 15-36). Berlin, Heidelberg: Springer International Publishing. https:// doi.org/10.1007/978-3-540-36763-5_2

De Groot, R. S. (1992). Functions of nature: Evaluation of nature in environmental planning, management and decision making. Functions of Nature: Evaluation of Nature in Environmental Planning, Management and Decision Making. Retrieved from https:/www.cabdirect.org/cabdirect/ abstract/19931980587

Dinh, H. (2017). Doctoral thesis: Studying plant diversity in Xuan Nha Nature Reserve, Son La province. Forestry University.

Dunets, A. N. (2013). Approach to the study of tourist development of mountain regions. Karadeniz International Scientific Journal, 1(20), 13-21. Retrieved from https://dergipark.org.tr/ tr/pub/kdeniz/175365

EricT. Jeannings Translators Pham Viem Phuong and Bui Thanh Chau. (2015). Da Lat and the fall and rise of French Indochina. Hanoi, Vietnam: Hong Duc Publishing House.

European Commission. (2017). Urban strategies for Waste Management in Tourist Cities. - Ecosystem services and tourism in the URBAN WASTE pilot cities. European Commission.

File number 74505. RST. A.s creation of sanatoriums in the provinces of Laokay, Son La, Vinh Yen 1904-1919. (1919). The source of the document is archived in French at the National Library of Vietnam-VNRN I, Hanoi.

Forman, R. T. (1981). Interaction among landscape elements: A core of landscape ecology. Perspectives in Landscape Ecology, $35-48$.

Giang, L. (2011). Pilgrimage, the experience in yourself. Spiritual Travel Magazine - A Pilgrimage Guide, 2-3.

Gössling, S. (1999). Ecotourism: A means to safeguard biodiversity and ecosystem functions? Ecological Economics, 29(2), 303320. https://doi.org/10.1016/S0921-8009(99)00012-9

Gössling, S., Hall, C. M., \& Scott, D. (2015). Tourism and water (Vol. 2). Bristol, UK: Channel View Publications.

Hermes, J., Albert, C., \& von Haaren, C. (2018). Assessing the aesthetic quality of landscapes in Germany. Ecosystem Services, 31, 296-307. https://doi.org/10.1016/j.ecoser.2018.02.015 
Ixatsenko, A. G. (1969). Basis of landscape and natural geographic zoning. Hanoi, Vietnam: Science Publishing House.

Kumar, P. (2010). The economics of ecosystems and biodiversity: Ecological and economic foundations. UNEP/Earthprint.

Le, B. (1977). Vietnam Nature. Hanoi, Vietnam: Hanoi Science and Technology Publishing House.

Le, H. T. T., Nguyen, N. N., Trinh, H. T. T., \& Viet, T. P. (2020). Climate Resources for Tourism: Case of Moc Chau Plateau, Vietnam. Journal of Social and Political Sciences, 3(3). https:// doi.org/10.31014/aior.1991.03.03.198

Lertputtarak, S. (2012). The Relationship between Destination Image, Food Image, and Revisiting Pattaya, Thailand. International Journal of Business and Management, 7(5), p111. https://doi.org/10.5539/ijbm.v7n5p111

Lin, Y., Pearson, T. E., \& Cai, L. A. (2011). Food as a form of destination identity: A tourism destination brand perspective. Tourism and Hospitality Research: The Surrey Quarterly Review, 11(1).

Mander, Ü., \& Uuemaa, E. (2015). Landscape Planning. In: Encyclopedia of Ecology (pp. 532-544). Elsevier. https://doi. org/10.1016/B978-0-12-409548-9.09478-1

Mieczkowski, Z. (1985). The Tourism Climatic Index: A Method of Evaluating World Climates for Tourism. The Canadian Geographer / Le Géographe Canadien, 29(3), 220-233. https:// doi.org/10.1111/j.1541-0064.1985.tb00365.x

Morgan, R., Gatell, E., Junyent, R., Micallef, A., Özhan, E., \& Williams, A. T. (2000). An improved user-based beach climate index. Journal of Coastal Conservation, 6(1), 41-50. https:// doi.org/10.1007/BF02730466

National History of the Nguyen Dynasty. (1992). Dai Nam Nhat Thong Tri. Hanoi, Vietnam: Thuan Hoa Publishing House.

Nguyen, A. T. (2003). Ecological landscape. Theory and practical applications in the humid tropical monsoon environment. Hanoi, Vietnam: Science-Technology Publishing House.

Nguyen, N. K. (2019). Draft content of management and protection of important natural landscapes in the draft decree guiding the implementation of environmental protection law.

Nguyen, X. T. (2020). Factors That Influence the Intentions to Revisit Korea of Vietnamese Tourists. Journal of Asian Finance, Economics and Business, 7(4), 247-258. https://doi. org/10.13106/jafeb.2020.vol7.no4.247

Nha, K. (2018). The challenge of tourism in Vietnam before the impact of climate change. Ministry of Natural Resources and Environment, Department of Climate Change, Hanoi, Vietnam.

Nyaupane, G. P., \& Chhetri, N. (2009). Vulnerability to climate change of nature-based tourism in the Nepalese Himalayas. Tourism Geographies, 11(1), 95-119.
Paul Doumer, Translator Nguyen Xuan Khanh. (1897). Indochina. Hanoi, Vietnam: World Publishing House.

People's Committee of Moc Chau District. (2015). Report on reviewing, adjusting and supplementing the master plan on socio-economic development of Moc Chau district till 2020.

People's Committee of Moc Chau District. (2016). Moc ChauExperience-Explore.

Pham, H. H. (1990). General assessment of natural conditions, natural resources of tropical, humid monsoon and tropical coastal areas of Vietnam for the purpose of developing agriculture-Forestry production and protecting the environment.

Pham, H. H., Nguyen, T. H., \& Nguyen, N. K. (1997). Landscape basis of the rational use of natural resources and environmental protection of the territory of Vietnam. Hanoi, Vietnam: Education Publishing House.

Ratknić, T., \& Milovanovic, J. (2016). Medicinal herbs as part of the development of sustainable tourism in Nature park "Stara Planina." https://doi.org/10.5937/ekoPolj1603847R

Skowronek, E., Tucki, A., Huijbens, E., \& Jóźwik, M. (2018). What is the tourist landscape? Aspects and features of the concept. Acta Geographica Slovenica, 58(2), 73-85-73-85. https://doi. org/10.3986/AGS.3311

Son La Statistical Office. (2019). Son La Statistical Yearbook.

Spalding, M., Burke, L., Wood, S. A., Ashpole, J., Hutchison, J., \& zu Ermgassen, P. (2017). Mapping the global value and distribution of coral reef tourism. Marine Policy, 82, 104-113. https://doi.org/10.1016/j.marpol.2017.05.014

Telfer, D. J., \& Wall, G. (2000). Strengthening backward economic linkages: Local food purchasing by three Indonesian hotels. Tourism Geographies, 2(4), 421-447.

Thai H. (2019). Current trend of developing healthcare tourism in the world-Tourism Development Research Institute (ITDR). Retrieved September 17, 2020, from http://itdr.org.vn/xuhuong-phat-trien-du-lich-cham-soc-suc-khoe-tren-the-gioihien-nay/

Torabi Farsani, N., Zeinali, H., \& Moaiednia, M. (2018). Food heritage and promoting herbal medicine-based niche tourism in Isfahan, Iran. Journal of Heritage Tourism, 13(1), 77-87.

UNWTO (Ed.). (2010). Tourism and Biodiversity Achieving Common Goals Towards Sustainability. World Tourism Organization (UNWTO). https://doi. org/10.18111/9789284413713

UNWTO (Ed.). (2018). Sustainable Mountain Tourism Opportunities for Local Communities, Executive Summary. World Tourism Organization (UNWTO). https://doi. org/10.18111/9789284420285 